\title{
Hydrogarnet Formation in the System Lime-Alumina-Silica-Water
}

\author{
Elmer T. Carlson
}

\begin{abstract}
Glasses of the composition of grossularite and similar glasses poorer in silica were treated hydrothermally, and the composition of the resulting hydrogarnets was estimated from the unit cell size as calculated from X-ray powder patterns. The silica content of the hydrogarnets increased continuously with the temperature of formation, approximating that of grossularite at $800^{\circ} \mathrm{C}$. When mixtures of lime, alumina, and silica, either as such or in various states of combination, were treated in the same manner as the glasses, equilibrium was not attained even after several weeks. At times as many as three distinct hydrogarnet compositions were found to coexist. The equilibrium temperature for the hydrothermal decomposition of $3 \mathrm{CaO} \cdot \mathrm{Al}_{2} \mathrm{O}_{3} \cdot 6 \mathrm{H}_{2} \mathrm{O}$ to $4 \mathrm{CaO} \cdot 3 \mathrm{Al}_{2} \mathrm{O}_{3} \cdot 3 \mathrm{H}_{2} \mathrm{O}$ plus $\mathrm{Ca}(\mathrm{OH})_{2}$ was found to be between $220^{\circ}$ and $226^{\circ} \mathrm{C}$. Hydrogarnets containing increasing amounts of silica underwent the same type of decomposition at progressively higher temperatures.
\end{abstract}

\section{Introduction}

The relationship between the isometric tricalcium aluminate hexahydrate and grossularite garnet was pointed out by Flint, McMurdie, and Wells $[1,2] .{ }^{1}$ It was shown that these two compounds are the end members of a series of solid solutions, of garnet-like crystalline structure, which were termed "hydrogarnets." The general formula may be written, $3 \mathrm{CaO} \cdot \mathrm{Al}_{2} \mathrm{O}_{3} \cdot m \mathrm{SiO}_{2} \cdot(6-2 m) \mathrm{H}_{2} \mathrm{O}$, where $m$ may vary from 0 to 3 . The present work is an extension of these earlier studies, undertaken for the purpose of answering certain questions not previously covered completely.

The first of these questions to be considered is the relation between temperature and pressure and the composition of the hydrogarnet in equilibrium with the fluid phase. Flint and Wells prepared their hydrogarnets from mixtures of various raw materials in the desired lime-alumina-silica ratios, selecting by trial-and-error methods the optimum temperature for each preparation. In general, the results obtained at other temperatures were not reported. It has been pointed out by Yoder [3] that theoretically the composition of the solid-solution phase at equilibrium should be a function of temperature and pressure. This was supported by his data, on the basis of which he constructed a pressure-temperature diagram showing the variation in refractive index of the hydrogarnet phase. With the exception of one point, all his data were obtained at $500^{\circ} \mathrm{C}$. or higher. It was considered desirable to obtain some data at lower temperatures.

Another objective of the present study is to determine how the course of the reaction is affected by the choice of raw materials. In theory, the composition of the product at a given temperature and pressure should be independent of the previous state of the reactants; nevertheless, it was found by Flint and Wells that different results were obtained with different starting materials. It must be assumed that this was due to nonequilibrium conditions.

\footnotetext{
1 Figures in brackets indicate the literature references at the end of this paper.
}

Such conditions are likely to exist in actual practical processes involving formation of hydrogarnet; hence a study of these variations should be of some interest.

Finally, there is the question of the upper limit of stability of the hydrogarnets under hydrothermal conditions. Flint, and McMurdie, and Wells [1] stated that a sample of tricalcium aluminate hexahydrate containing a small amount of silica was stable up to $300^{\circ} \mathrm{C}$, at which point it decomposed to calcium hydroxide and gibbsite. However, it was later shown by Johnson and Thorvaldson [4] that pure tricalcium aluminate hexahydrate under these conditions breaks down to form a less basic aluminate, $4 \mathrm{CaO} \cdot 3 \mathrm{Al}_{2} \mathrm{O}_{3} \cdot 3 \mathrm{H}_{2} \mathrm{O}$, plus calcium hydroxide. This was confirmed by Peppler and Wells [5], who placed the decomposition temperature at about $215^{\circ} \mathrm{C}$. A study of the effect of silica on this reaction appeared desirable.

The work of Flint, McMurdie, and Wells included also a series of quinary compositions, the fifth component being ferric oxide. This is omitted from consideration in the present paper.

\section{Materials, Apparatus, and Procedures}

\subsection{Materials}

The alumina used was a commercial preparation of gibbsite $\left(\mathrm{Al}_{2} \mathrm{O}_{3} \cdot 3 \mathrm{H}_{2} \mathrm{O}\right)$ containing about 0.30 percent of $\mathrm{Na}_{2} \mathrm{O}$, other impurities being negligible in amount. All other raw materials, except as otherwise noted, were reagent grade chemicals. Ordinary distilled water was used without further purification.

\subsection{Apparatus}

Most of the reactions were carried out in stainlesssteel pressure bombs of the Morey type. The bombs were heated in vertical tube furnaces, and the temperature was automatically controlled and recorded by conventional apparatus using iron-constantan thermocouples. The temperature gradient in each furnace was carefully explored, and the bombs were positioned so that a thermocouple in the normal recording position and another at the bottom of the 
bomb chamber gave readings agreeing within 1 deg. This minimized an error that might otherwise have been as great as $10 \mathrm{deg}$, judging from preliminary tests.

No provision was made for independent pressure control, hence the pressure developed in the bomb was a function of temperature and of the degree of filling of the bomb. For temperatures below the critical point, excess liquid water was present, and the pressure was estimated from steam tables. For higher temperatures the pressure-volume-temperature data of Kennedy [6] were used.

A cold-seal hydrothermal apparatus of the type designed by Tuttle [7] was also used, permitting extension of the study to higher temperatures. In this apparatus, both pressure and temperature were controlled manually. A pressure of 15,000 psi was used, except for a few experiments on the effect of varying pressure.

\subsection{Procedures}

The solid reactants, lime, alumina, and silica, may be introduced in a variety of forms or states of combination. The separate oxides, or hydrates, for example, may be mixed. When this procedure was used, the lime was usually present as the oxide (freshly prepared by calcining the carbonate), the alumina as gibbsite, and the silica as gel ("silicic acid").

Alternatively, two or more of the components may be chemically combined. For example, tricalcium aluminate was prepared by heating a mixture of calcium carbonate and alumina; likewise, tricalcium silicate from calcium carbonate and silica. Tricalcium aluminate hexahydrate was prepared (a) by hydration of tricalcium aluminate at $150^{\circ}$ to $200^{\circ} \mathrm{C}$, and (b) by the reaction between lime and freshly precipitated alumina at boiling temperature. The latter method was also modified by the copre. cipitation of small amounts of silica with the alumina. Three hydrogarnet preparations were obtained by this method, containing $0.10,0.26$, and 0.58 mole of $\mathrm{SiO}_{2}$ per mole of $\mathrm{Al}_{2} \mathrm{O}_{3}$, respectively. However, as is shown later, in the last of these not all the silica was present in the hydrogarnet. In lieu of a synthetic aluminum silicate, Georoia kaolin, activated by heating at $750^{\circ} \mathrm{C}$, was used for a few experiments.

Finally, there is the possibility of using ternary glasses in which the three components are present in the desired proportions. Glasses were prepared by heating mixtures of calcium carbonate, gibbsite, and silica gel in a Globar-type furnace. The lime:alumina ratio was kept at 3 to 1 , whereas the silica: alumina ratio ranged from 0.4 to 3.0. Mixtures that did not fuse at the highest temperature of the furnace (about $1,450^{\circ} \mathrm{C}$ ) or that devitrified on cooling were given further treatment. Fragments were held in an oxygen-gas blast until fused to a clear glass, and the molten drops were quenched in water. The glass was ground to pass a No. 200 sieve, before hydrothermal treatment.

The starting materials, totaling a few tenths of a gram, usually were mixed with water to a paste or slurry in a small platinum crucible, which was then placed in the bomb with the desired quantity of water and kept in a furnace at constant temperature ( \pm 3 deg C) for several days. When the cold-seal apparatus was used, the weight of solids averaged about $0.05 \mathrm{~g}$, and the amount of water was generally between 0.02 and $0.05 \mathrm{~g}$. The mixture was enclosed in a small platinum capsule, which was then placed in the bomb; the bomb was connected to the pressure line, the pressure raised, and the heat applied. The warmup period averaged about $30 \mathrm{~min}$. After a heating period ranging from a few hours to 3 days, the bomb was cooled in air (usually requiring about $15 \mathrm{~min}$ ) and opened.

As a general procedure, the solid reaction products were filtered off and dried by washing with alcohol and ether. Frequently, when the Morey bombs were opened, the reaction products were almost dry; in such cases the drying was completed in an oven at about $100^{\circ} \mathrm{C}$, without intervening filtration.

The dried products were first examined under the polarizing microscope, after which X-ray powder diffraction patterns usually were obtained. The patterns were made with a recording X-ray diffractometer, using copper $K \alpha$ radiation. The $\mathrm{X}$-ray patterns served not only for identification of crystalline phases, but also as a means of estimating the composition of the hydrogarnet solid solution. It was shown by Flint, McMurdie, and Wells [1] that the hydrogarnets crystallize in the isometric system, and that the unit cell size is a function of composition. In the solid solution series $3 \mathrm{CaO} \cdot \mathrm{Al}_{2} \mathrm{O}_{3} \cdot 3 \mathrm{SiO}_{2}-3 \mathrm{CaO}$. $\mathrm{Al}_{2} \mathrm{O}_{3} \cdot 6 \mathrm{H}_{2} \mathrm{O}$, the cell constant was found to range from 11.84 to $12.56 \mathrm{~A}$. On the basis of data from several sources, Yoder [3] presents a diagram showing the relation between composition and cell constant in this series. The relation is shown to be nearly, but not quite, linear. Thus if the cell constant is known, the composition can be estimated with fair precision.

The cell constant may be readily calculated from the interplanar spacings, which in turn are derived from the X-ray diffraction angles. For accurate measurement of the angles it is necessary to have a sharp, distinct pattern, also to have a standard present for comparison. In many of the reaction products discussed in the following sections, calcium hydroxide was present, serving as a reliable internal standard. The calculated unit cell sizes are believed to be accurate to $\pm 0.01 \mathrm{~A}$ for the determinations in which an internal standard was present, and $\pm 0.03 \mathrm{~A}$ otherwise.

In numerous cases, as is discussed later, there was clear evidence of the presence of two, or occasionally three, separate hydrogarnet compositions in the same reaction product. It seems evident that, in such cases, equilibrium had not been attained. Although the condition usually could not be detected microscopically, it was disclosed by the X-ray patterns, in which many of the prominent lines appeared either as doublets or as pairs (occasionally triads) of lines, depending on the relative compositions. When this occurred, only the low- and medium-angle reflections could be relied on, as there was considerable overlapping at the higher angles. 


\section{Results and Discussion}

\subsection{Relation Between Temperature and Composition}

The phase equilibrium relationships involved in this study are complex, because the system is quaternary, the temperature range extends beyond the critical point for water, and the phase of primary interest is a solid solution. A discussion of the theoretical aspects is beyond the scope of this paper. However, it may be mentioned that there can be as many as four solid phases (five, above the critical temperature) existing together at equilibrium, hence the presence of other solid phases along with the hydrogarnet is not evidence of failure to reach equilibrium. On the other hand, the coexistence of two solid phases that are members of the same solid solution series would indicate lack of attainment of equilibrium. This condition was observed in a number of instances reported in the tables. The converse, that a single hydrogarnet phase indicates equilibrium, is not necessarily valid. Nevertheless, in the absence of any better criterion, the observation of a single well-defined hydrogarnet phase, independent of the duration of treatment within the limits of the experimental conditions, is herein taken to indicate the attainment of equilibrium.

After numerous experiments with various starting materials it was concluded that the glasses yielded equilibrium products more readily than did any of the other combinations. The data in table 1 , therefore, were obtained entirely from experiments with glasses.

The crystals formed were always very small, often barely visible under the microscope, so that it was usually difficult to determine the refractive index even approximately. In some cases, particularly with the low-silica glasses, hydration and crystallization appeared to take place without altering the shape of the glass fragments.

Table 1 presents the results of two series of experiments: (A) those in which the Morey-type bombs

TABLE 1. Hydrothermal reactions of glasses of composition $\mathrm{C}_{3} \mathrm{AS}_{\mathrm{m}}$

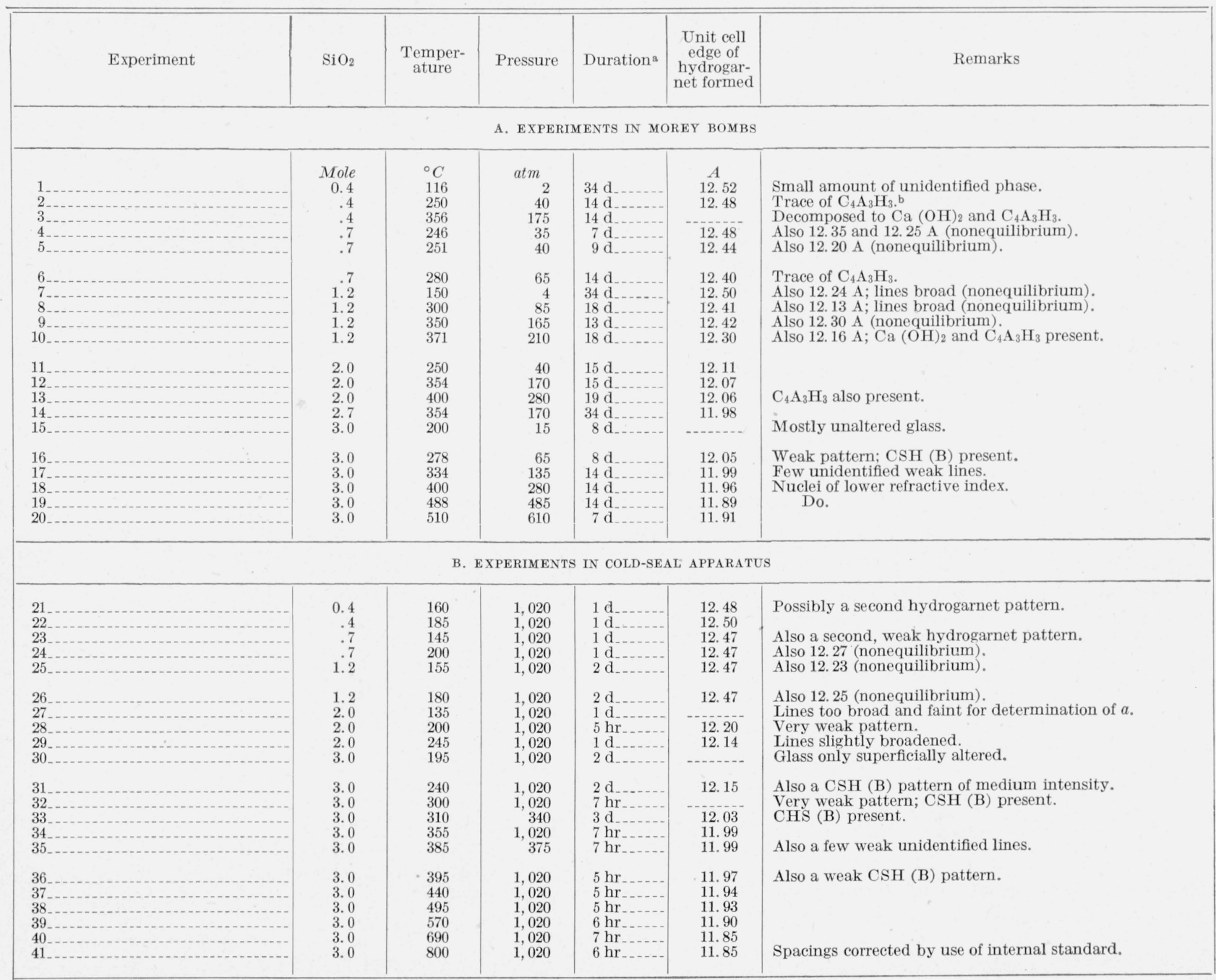


were used, and (B) those in which the cold-seal apparatus was used. Within each series the arrangement is in order of increasing silica content and increasing temperature.

Figure 1 is based on the data in table 1, with the omission of those experiments in which there is evidence that equilibrium was not reached. Here the unit cell size (a function of composition) is plotted against temperature of formation. The relation between composition and unit cell size is probably not quite linear. The composition lines adjacent to the vertical scale of figure 1 are based on Yoder's diagram [3], to which reference was made earlier.

Attainment of equilibrium was slow. For example, in experiment 9 , after 13 days at $350^{\circ} \mathrm{C}$, the $\mathrm{X}$-ray pattern indicated the presence of two distinct hydrogarnet compositions, with cell constants 12.42 and $12.30 \mathrm{~A}$, respectively. This is evidence of nonequilibrium conditions. With the higher pressures attainable in the cold-seal apparatus, equilibrium was reached more quickly, but even here there was evidence of variable composition, in that the crystals often contained nuclei of lower refractive index than that of the surrounding shell. This indicates a relative deficiency in silica in the nuclei of the crystals, from which it is assumed that these may have formed at lower temperatures, during the warmup period. In most cases the amount was insufficient to affect the X-ray diffraction pattern, but it was often enough to interfere with a precise determination of index of refraction. For this reason, and also because an extraneous siliceous phase usually was present as a product of the reaction, little success was achieved in correlating the index of refraction with the composition derived from the X-ray pattern.

Considering first the data for the glass with 3 moles of silica (that is, having the composition of grossularite), it is seen that at the two highest temperatures a product was obtained having a unit cell edge of $11.85 \mathrm{~A}$. The corresponding figure reported for grossularite is $11.84 \mathrm{~A} \mathrm{[1],} \mathrm{or} 11.85$ [3]. The pattern for experiment 41 was prepared with the inclusion of an internal standard (tungsten), hence the lattice constant given for this product is probably

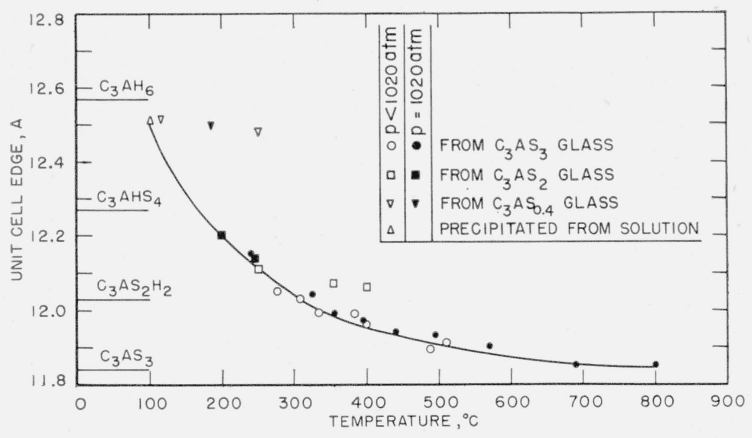

FIGURE 1. Relation between temperature of formation and unit cell edge for hydrogarnets in the system $\mathrm{CaO}-\mathrm{Al}_{2} \mathrm{O}_{3}-$ $\mathrm{SiO}_{2}-\mathrm{H}_{2} \mathrm{O}$.

The letters $\mathrm{C}, \mathrm{A}, \mathrm{S}$, and $\mathrm{H}$ denote the oxides $\mathrm{CaO}, \mathrm{Al}_{2} \mathrm{O}_{3}, \mathrm{SiO}_{2}$, and $\mathrm{H}_{2} \mathrm{O}$, respectively. correct to \pm 0.01 A. Because of the extreme fineness of the material it was impossible to make a satisfactory determination of refractive index. The loss on ignition was zero, within the limits of analytical error. This fact, considered with the X-ray data, makes it evident that the product was very close to the composition of grossularite.

At lower temperatures of formation the cell constant is progressively larger, indicating that the composition is poorer in silica and richer in water. Here the X-ray patterns are weaker, the lines often broader, and lines of other crystalline phases appear together with those of the hydrogarnet. This is understandable, as the silica content of the hydrogarnet is now less than that of the glass. The excess silica reacts with part of the lime, thus reducing the amount of the latter available for hydrogarnet formation. Some alumina is thereby left unaccounted for, but the form in which it is present is not known. The identity of the calcium silicate may be considered established in at least a few cases. The product of experiment 31 gave an X-ray pattern of moderate intensity, which, after subtraction of the hydrogarnet lines, agrees rather well with that given by Heller and Taylor [8], for $\mathrm{CSH} \mathrm{I}^{2}(\mathrm{CSH}(\mathrm{B})$ according to Bogue's classification [9]). With this as a standard for comparison, the presence of much smaller amounts of the same phase was detected in several other preparations. In a few cases, however, the extraneous lines did not fit this pattern.

At lower temperatures the reaction becomes progressively slower. Thus after 2 days at $195^{\circ} \mathrm{C}$ (experiment 30) there was little evidence of alteration of the glass. Glasses poorer in silica were found to react more readily, and were therefore used in the experiments at the lower temperatures. The silica content of the hydrogarnet appeared to be independent of that of the parent glass (compare, for example, experiments 29 and 31 ), except that the hydrogarnet was never richer in silica than the glass. This limitation accounts for the points in figure 1 that fall significantly above the curve. Such a departure should not occur if the mixtures have reached equilibrium (assuming that the curve is a true equilibrium line). Probably the explanation will have to await a more complete study of the quaternary system.

Even with the low-silica glasses, the results at the lowest temperatures were rather unsatisfactory. The point plotted in figure 1 for $100^{\circ} \mathrm{C}$ represents a hydrogarnet prepared not from a glass but from a boiling mixture of lime water, alumina, and sodium silicate, with the silica in moderate excess.

The use of the low-silica glasses at the higher temperatures is also limited by the breakdown of the hydrogarnet phase to $4 \mathrm{CaO} \cdot 3 \mathrm{Al}_{2} \mathrm{O}_{3} \cdot 3 \mathrm{H}_{2} \mathrm{O}$ (see experiments $2,3,6,10$, and 13 ).

To determine the effect of varying pressure on the composition of the hydrogarnet, experiments 33 and 35 were conducted at lower pressures than the other

2 In the interest of brevity, the convention of using the letters C, A, S, and $\mathrm{H}$ to represent $\mathrm{CaO}, \mathrm{Al}_{2} \mathrm{O}_{3}, \mathrm{SiO}_{2}$, and $\mathrm{H}_{2} \mathrm{O}$, respectively, is followed throughout this paper. 
members of this series. The pressures in the Morey bombs (experiments 1 to 20) were likewise lower. In figure 1, the experiments at 1,020 atm are represented by filled symbols; those at lower pressures by open symbols. The fact that a single curve approximates both sets of points indicates that pressure is of relatively little effect within the range covered. A similar conclusion was reached by Yoder on the basis of results at higher temperatures [3].

\subsection{Hydrothermal Reactions of Heterogeneous Lime- Alumina-Silica Mixtures}

In the experiments described below, the solid components were present initially not as a homogeneous glass but as mixtures of various compounds. In most cases the results departed more or less from those of the comparable experiments with glasses, as described above. This is ascribed to lack of attainment of equilibrium in the heterogeneous mixtures. The results obtained, nevertheless, may be of interest, as the experimental conditions are more closely related to those that may exist in actual practical processes.

The data presented in tables 2 to 5 are representative of a considerably larger number of experiments. The data given were selected not only to illustrate general trends but to point out anomalies as well.

a. Mixtures of Tricalcium Aluminate and Tricalcium Silicate

The hydration of tricalcium aluminate in the presence of tricalcium silicate is of some interest because it represents, in greatly simplified form, the reactions of the aluminate phase of cement clinker during hydration. In the series of experiments recorded in table 2 , the ratio of $\mathrm{C}_{3} \mathrm{~S}$ to $\mathrm{C}_{3} \mathrm{~A}$ ranged from 0.7 to 3.0. The ratio is well below that existing in normal portland cements, but the present study is concerned primarily with the hydrogarnet phase, in which the ratio of silica to alumina does not exceed 3.0 .

Several facts may be noted. Perhaps the most obvious is that in most cases equilibrium was not attained even after 35 days (experiments 4, 11). This is evidenced by the coexistence of two or more hydrogarnet phases. Furthermore, a comparison of experiments Nos. 3 and 4 indicates no progress toward equilibrium between 1 and 35 days. In all the experiments below $170^{\circ} \mathrm{C}$, and in some as high as $182^{\circ} \mathrm{C}$ (experiments 15,21 ) there was evidence of only one hydrogarnet phase and this had the unit cell size $(12.57 \mathrm{~A})$ of tricalcium aluminate hexahydrate. It must be borne in mind that the presence or absence of the second hydrogarnet phase was determined by examination of the X-ray patterns, and as a result the presence of such a phase in small amounts would fail to be observed. Nevertheless, it appears that the aluminate and silicate phases have hydrated separately at the lower temperatures. On the other hand, above $225^{\circ} \mathrm{C}$, and in some cases as low as $201^{\circ} \mathrm{C}, 3 \mathrm{CaO} \cdot \mathrm{Al}_{2} \mathrm{O}_{3} \cdot 6 \mathrm{H}_{2} \mathrm{O}$ is absent, and only the siliceous hydrogarnet is observed. This may occur even after only 1 day (experiment 17 ).
The unit cell size of the siliceous hydrogarnet varies little with the quantity of silica in the reaction mixture, and apparently not at all with temperature, except for a few random inconsistencies. On the basis of Yoder's diagram, previously cited, the $12.40 \mathrm{~A}$ unit cell would indicate about 0.5 mole of $\mathrm{SiO}_{2}$ per mole of $3 \mathrm{CaO} \cdot \mathrm{Al}_{2} \mathrm{O}_{3}$, and $12.32 \mathrm{~A}$ would correspond to about 0.8 mole of $\mathrm{SiO}_{2}$. In no case would this account for all the silica present; hence part of the silica must be present in another phase. In two instances (experiments 9 and 22) there is evidence of a small amount of hydrogarnet with somewhat higher silica, but these appear to be exceptions. Experiment 8 also fails to conform to the general pattern.

TABLE 2. Hydrothermal reactions of mixtures of tricalcium aluminate and tricalcium silicate

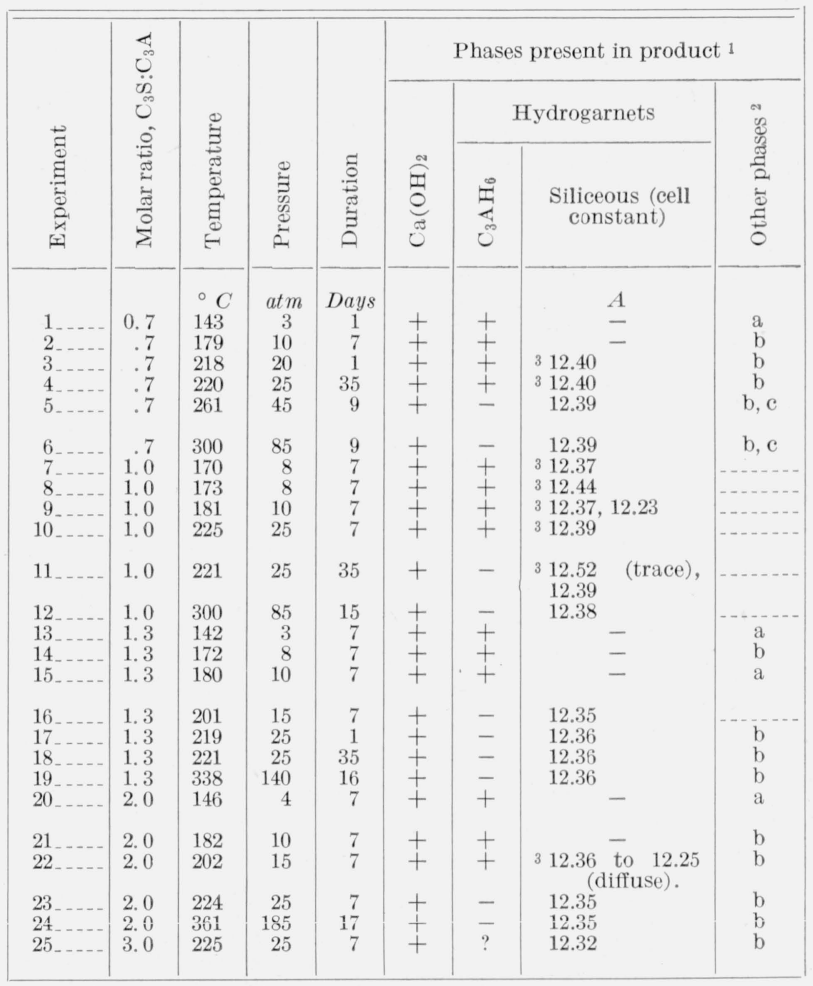

$1+$ indicates present; - , absent

2 " $\mathrm{a}$ " is believed to be C'SH (CSH(A), according to Bogue's classification); "b" is probably $\mathrm{C}_{2} \mathrm{~S} \gamma$-hydrate $\left(\mathrm{C}_{2} \mathrm{SH}(\mathrm{C})\right.$, according to Bogue's classification); "c" is unidentified.

3 From coexistence of hydrogarnet phases it is concluded that equilibrium was not attained.

All the reaction products contained free calcium hydroxide, as would be expected. In most cases the X-ray patterns showed a few weak or medium lines that could not be attributed either to a hydrogarnet or to $\mathrm{Ca}(\mathrm{OH})_{2}$. Unaccountably, such lines were conspicuously absent from the patterns of experiments 7 to 12 , in which equimolar amounts of the aluminate and silicate were initially present, although with both higher and lower proportions of silica the lines were observed. Interpretation of the patterns is highly speculative, because most of the lines were very weak, and undoubtedly many still weaker lines were masked by the patterns of the predominant 
phases. It is reasonable to assume that they represent one or more hydrated calcium silicates. Most of the extraneous patterns were of two types, here designated "a" and "b." The former bears some resemblance to that of the $\mathrm{CaO} \cdot \mathrm{SiO}_{2} \cdot \mathrm{H}_{2} \mathrm{O}$ described by McMurdie and Flint [10], designated CSH (A) by Bogue [9], although the fit is imperfect. The "b" pattern resembles that of the so-called $\mathrm{C}_{2} \mathrm{~S}$ $\gamma$-hydrate, which Bogue calls $\mathrm{C}_{2} \mathrm{SH}(\mathrm{C})$. Here again the fit is not perfect, but better than in the previous case. The possibility remains, of course, that these patterns are indicative of one or more quaternary compounds or solid solutions of unknown composition.

Although the identity of the calcium silicate hydrates formed in these reactions cannot be considered well established, it is significant that there is no evidence of the presence of either xonotlite or hillebrandite, which Peppler [11] has shown to be the stable phases in the $\mathrm{CaO}-\mathrm{SiO}_{2}-\mathrm{H}_{2} \mathrm{O}$ system under equivalent conditions of temperature and pressure.

\section{b. Mixtures of $3 \mathrm{CaO} \cdot \mathrm{Al}_{2} \mathrm{O}_{3} \cdot 6 \mathrm{H}_{2} \mathrm{O}$ with Silica or Calcium Silicate Hydrate}

It is of interest to ascertain how tricalcium aluminate hexahydrate, prepared in the absence of silica, reacts on subsequent treatment in the presence of silica. The data presented in table 3 are typical of the results of a considerable number of experiments of this nature. In experiments 1 to 10 the silica was present as silica gel. As previously noted by Flint and Wells [2], the aluminate takes up silica under these conditions, forming silica-bearing hydrogarnets. Flint and Wells relied on refractive index measurements in estimating the amount of silica taken up. The X-ray diffraction method employed in the present work provides a somewhat more precise indication of the silica content. It is clear that experiments 3,5 , and 6 failed to reach equilibrium, because a new hydrogarnet phase is seen to exist together with part of the original $3 \mathrm{CaO} \cdot \mathrm{Al}_{2} \mathrm{O}_{3} \cdot 6 \mathrm{H}_{2} \mathrm{O}$. By the use of higher temperatures and pressures, equilibrium apparently was obtained. The product of experiment 10 was of almost the same composition as that obtained by treatment of the ternary glass under similar conditions. As in the experiments with the glasses, several of the reaction products formed at the lower temperatures contained hydrated calcium silicate $\mathrm{CSH}(\mathrm{B})$. In a few instances the extraneous lines in the X-ray patterns could not be positively identified.

In experiments 11 to 13 the silica was initially present as a synthetic gel of approximate composition CSH, whereas for Nos. 14 to 16 a synthetic $\mathrm{C}_{2} \mathrm{SH}$ (B) containing about 10 percent of xonotlite was used. These preparations reacted readily with the aluminate, forming $\mathrm{Ca}(\mathrm{OH})_{2}$ and a siliceous hydrogarnet. No consistent relation is observed between composition of the hydrogarnet and temperature of formation; also there is evidence of failure to reach equilibrium.

\section{c. Mixtures of Calcium Hydroxide and Dehydrated Kaolin}

Among the possible practical aspects of hydrogarnet formation is the reaction between lime and pozzolanic materials, particularly if conducted at elevated temperatures. Pozzolans usually contain both silica and alumina in active form. A sample of Georgia kaolin, activated by heating at $700^{\circ} \mathrm{C}$, was used as a representative material of this type. Table 4 gives the results of a few experiments with mixtures of lime with the activated kaolin. The ratio of reactants was such as to give an over-all composition of $3 \mathrm{CaO}: \mathrm{Al}_{2} \mathrm{O}_{3}: 2 \mathrm{SiO}_{2}$.

Like the other mixtures described above, the limekaolin mixtures failed to reach equilibrium during the

TARLE 3. Hydrothermal reactions between $3 \mathrm{CaO} \cdot \mathrm{Al}_{2} \mathrm{O}_{3} \cdot 6 \mathrm{H}_{2} \mathrm{O}$ and silica present as gel or hydrositicate

\begin{tabular}{|c|c|c|c|c|c|c|c|c|c|}
\hline \multirow{3}{*}{ Experiment } & \multirow{3}{*}{ Siliceous compound } & \multirow{3}{*}{$\begin{array}{l}\text { Molar } \\
\text { ratio, } \\
\mathrm{S}: \mathrm{C}_{3} \mathrm{~A}\end{array}$} & \multirow{3}{*}{$\begin{array}{l}\text { Temper- } \\
\text { ature }\end{array}$} & \multirow{3}{*}{$\begin{array}{l}\text { Pres- } \\
\text { sure }\end{array}$} & \multirow{3}{*}{$\begin{array}{l}\text { Dura- } \\
\text { tion }{ }^{a}\end{array}$} & \multicolumn{4}{|c|}{ Phases present in product $b$} \\
\hline & & & & & & \multirow[b]{2}{*}{$\mathrm{Ca}(\mathrm{OH})_{2}$} & \multicolumn{2}{|c|}{ Hydrogarnets } & \multirow[b]{2}{*}{ Other phases } \\
\hline & & & & & & & $\mathrm{C}_{3} \mathrm{AH}_{6}$ & $\begin{array}{l}\text { Siliceous (cell } \\
\text { constant) }\end{array}$ & \\
\hline $\begin{array}{l}1 \\
2 \\
3 \\
4 \\
5 \\
5\end{array}$ & \begin{tabular}{|l}
$\mathrm{SiO}_{2} \mathrm{gel}_{2}$ \\
\hdashline do \\
\hdashline do \\
\hdashline$-\mathrm{do}_{2}$
\end{tabular} & $\begin{array}{l}1.0 \\
1.0 \\
1.0 \\
1.5 \\
1.5\end{array}$ & $\begin{array}{l}\stackrel{\circ}{ }{ }^{\circ} \\
210 \\
225 \\
265 \\
236 \\
253\end{array}$ & $\begin{array}{r}a t m \\
20 \\
25 \\
50 \\
30 \\
40\end{array}$ & $\begin{array}{l}7 \mathrm{~d} \\
2 \mathrm{~d} \\
7 \mathrm{~d} \\
8 \mathrm{~d} \\
7 \mathrm{~d}\end{array}$ & $\begin{array}{l}\bar{z} \\
\bar{z} \\
\bar{z}\end{array}$ & $\begin{array}{l}+ \\
+ \\
+ \\
+ \\
+\end{array}$ & \begin{tabular}{c}
$A$ \\
\hdashline 12.07 \\
- \\
$c 12.05$
\end{tabular} & $\begin{array}{l}\mathrm{CSH}(\mathrm{B}) \\
\mathrm{CSH}(\mathrm{B}) \\
\mathrm{CSH}(\mathrm{B}) \\
\mathrm{CSH}(\mathrm{B})\end{array}$ \\
\hline $\begin{array}{r}6 \\
7 \\
8 \\
9 \\
90\end{array}$ & \begin{tabular}{|l} 
\\
\hdashline do \\
\hdashline
\end{tabular} & $\begin{array}{l}1.5 \\
3.0 \\
3.0 \\
3.0 \\
3.0\end{array}$ & $\begin{array}{l}344 \\
140 \\
355 \\
395 \\
715\end{array}$ & $\begin{array}{r}150 \\
1,020 \\
1,020 \\
1,020 \\
1,020\end{array}$ & $\begin{array}{l}7 \mathrm{~d} \\
1 \mathrm{~d} \\
6 \mathrm{hr} \\
1 \mathrm{~d} \\
6 \mathrm{hr}\end{array}$ & $\begin{array}{l}\bar{z} \\
\bar{z} \\
-\end{array}$ & $\begin{array}{l}+ \\
\pm \\
\pm \\
-\end{array}$ & $\begin{array}{l}\circ 11.99 \\
- \\
12.00(\mathrm{tr}) \\
11.97 \\
11.87\end{array}$ & $\begin{array}{c}\mathrm{C}_{4} \mathrm{~A}_{3} \mathrm{H}_{3}(?) \\
+ \\
\mathrm{CsH}(\mathrm{B}) \\
+ \\
-\end{array}$ \\
\hline $\begin{array}{l}11 \\
12 \\
13 \\
14 \\
15 \\
16\end{array}$ & 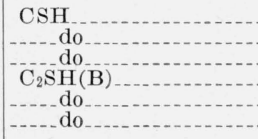 & $\begin{array}{l}1.0 \\
1.0 \\
1.5 \\
1.0 \\
1.0 \\
2.0\end{array}$ & $\begin{array}{l}249 \\
350 \\
350 \\
250 \\
350 \\
250\end{array}$ & $\begin{array}{r}40 \\
160 \\
160 \\
40 \\
160 \\
40\end{array}$ & $\begin{array}{l}7 \mathrm{~d} \\
7 \mathrm{~d} \\
7 \mathrm{~d} \\
7 \mathrm{~d} \\
7 \mathrm{~d} \\
7 \mathrm{~d}\end{array}$ & $\begin{array}{l}+ \\
+ \\
+ \\
+ \\
+ \\
+\end{array}$ & $\begin{array}{l}+ \\
+ \\
\text { tr. } \\
\text { tr. } \\
-\end{array}$ & $\begin{array}{r}c 12.23 \\
c 12.19 \\
c 12.23 \\
12.43 \\
\quad 12.19 \\
12.28\end{array}$ & $\begin{array}{l}\mathrm{C}_{2} \mathrm{SH}(\mathrm{B}) \\
\mathrm{C}_{2} \mathrm{SH}(\mathrm{B})\end{array}$ \\
\hline
\end{tabular}

a d=days; hr, hours.

$b$ +indicates present; - , absent; tr., trace

c From coexistence of hydrogarnet phases it is concluded that equilibrium was not attained. 
reaction period with the possible exception of experiment 7 . If in the product of each of the last four members of this series only the phase highest in silica (smallest in unit cell dimensions) be considered, the agreement with the equilibrium curve in figure 1 is good. It should be noted that the unit cell size in experiment 7 indicates nearly 3 moles of silica in the hydrogarnet, which value is higher than the proportion originally present. The excess lime and alumina are accounted for by the $\mathrm{Ca}(\mathrm{OH})_{2}$ and $4 \mathrm{CaO} \cdot 3 \mathrm{Al}_{2} \mathrm{O}_{3} \cdot 3 \mathrm{H}_{2} \mathrm{O}$ present.

TABLE 4. Hydrothermal reactions of mixtures of lime and activated kaolin

\begin{tabular}{|c|c|c|c|c|c|c|c|c|}
\hline \multirow{3}{*}{$\begin{array}{c}\text { Experi- } \\
\text { ment }\end{array}$} & \multirow{3}{*}{ 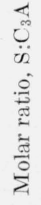 } & \multirow{3}{*}{ 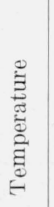 } & \multirow[b]{3}{*}{ 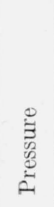 } & \multirow[b]{3}{*}{ } & \multicolumn{4}{|c|}{ Phases present in product a } \\
\hline & & & & & \multirow[b]{2}{*}{$\underbrace{\stackrel{\sigma}{0}}_{\tilde{\sigma}}$} & \multicolumn{2}{|r|}{ Hydrogarnets } & \multirow[b]{2}{*}{$\begin{array}{l}\text { Other } \\
\text { phases }\end{array}$} \\
\hline & & & & & & $\underbrace{ \pm}_{j}$ & $\begin{array}{l}\text { Siliceous (cell con- } \\
\text { stant) }\end{array}$ & \\
\hline $\begin{array}{l}1 \\
2 \\
3 \\
4 \\
5 \\
6 \\
7 \\
-\ldots\end{array}$ & $\begin{array}{l}2.0 \\
2.0 \\
2.0 \\
2.0 \\
2.0 \\
2.0 \\
2.0\end{array}$ & $\begin{array}{l}\circ C \\
180 \\
224 \\
261 \\
302 \\
349 \\
396 \\
445\end{array}$ & $\begin{array}{r}\text { atm } \\
10 \\
25 \\
45 \\
85 \\
160 \\
265 \\
385\end{array}$ & $\begin{array}{c}\text { Days } \\
10 \\
10 \\
10 \\
7 \\
7 \\
7 \\
7\end{array}$ & $\begin{array}{l}- \\
\overline{-} \\
\overline{+} \\
+ \\
+\end{array}$ & $\begin{array}{l}z \\
\bar{z} \\
\bar{z} \\
\bar{z}\end{array}$ & 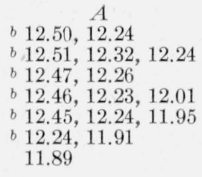 & 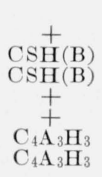 \\
\hline
\end{tabular}

$a+$ indicates present; - , absent

From coexistence of hydrogarnet phases it is concluded that equilibrium was not attained.

\section{d. Mixtures of the Hydrated Oxides}

In another short series of experiments, the reactants were present as hydrated oxides; the lime as hydroxide, the alumina as gibbsite, and the silica as gel. The ratio of lime to alumina was kept at 3 to 1 , as in the foregoing, but the silica was varied. The results are presented in table 5. Lack of attainment of equilibrium during the reaction period is again observed in certain cases. The occurrence of $4 \mathrm{CaO} \cdot 3 \mathrm{Al}_{2} \mathrm{O}_{3} \cdot 3 \mathrm{H}_{2} \mathrm{O}$ in experiments 1 and 3 deserves comment. It will be shown later that this phase would be expected to appear only at somewhat higher temperatures in the presence of silica in the amounts indicated in table 5. This may be taken as further evidence of lack of equilibrium.

TABLE 5. Hydrothermal reactions of mixtures of lime, alumina, and silica

\begin{tabular}{|c|c|c|c|c|c|c|c|c|}
\hline \multirow{3}{*}{$\begin{array}{l}\text { Experi- } \\
\text { ment }\end{array}$} & \multirow{3}{*}{ 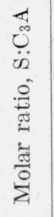 } & \multirow{3}{*}{ 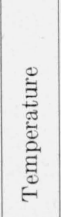 } & \multirow[b]{3}{*}{ 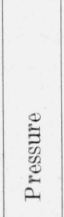 } & \multirow[b]{3}{*}{ 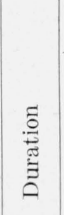 } & \multicolumn{4}{|c|}{ Phases present in product a } \\
\hline & & & & & \multirow[b]{2}{*}{$\underbrace{\tilde{\Xi}}_{\tilde{\Xi}}$} & \multicolumn{2}{|r|}{ Hydrogarnets } & \multirow[b]{2}{*}{$\begin{array}{l}\text { Other } \\
\text { phases }\end{array}$} \\
\hline & & & & & & $\sum_{j}^{\infty}$ & $\begin{array}{l}\text { Siliceous (cell con- } \\
\text { stant) }\end{array}$ & \\
\hline $\begin{array}{l}1 \\
2 \\
3 \\
4 \\
5 \\
6 \\
6\end{array}$ & $\begin{array}{r}0.2 \\
.2 \\
.5 \\
.5 \\
1.0 \\
1.0\end{array}$ & \begin{tabular}{|l|}
$\circ C$ \\
235 \\
285 \\
243 \\
275 \\
212 \\
301
\end{tabular} & $\begin{array}{c}\text { atm } \\
30 \\
65 \\
35 \\
60 \\
20 \\
85\end{array}$ & $\begin{array}{c}\text { Days } \\
5 \\
5 \\
4 \\
4 \\
9 \\
9\end{array}$ & $\begin{array}{l}+ \\
+ \\
+ \\
+ \\
\text { tr. } \\
-\end{array}$ & $\begin{array}{l}+ \\
\pm \\
+ \\
+ \\
+\end{array}$ & \begin{tabular}{|c|c}
\multicolumn{1}{c}{$A$} \\
\multicolumn{1}{c}{12.45} \\
12.49 \\
12.44 \\
o $12.47,12.16$ \\
o $12.48,12.27,11.97$
\end{tabular} & $\begin{array}{c}\mathrm{C}_{4} \mathrm{~A}_{3} \mathrm{H}_{3} \\
\mathrm{C}_{4} \mathrm{~A}_{3} \mathrm{H}_{3} \\
\mathrm{C}_{4} \mathrm{~A}_{3} \mathrm{H}_{3} \\
\mathrm{C}_{4} \mathrm{~A}_{3} \mathrm{H}_{3} \\
+ \\
+\end{array}$ \\
\hline
\end{tabular}

$a+$ indicates present; - , absent; tr., trace.

$b$ From coexistence of hydrogarnet phases it is concluded that equilibrium was not attained.

\subsection{Hydrothermal Decomposition of the Hydro- garnets}

As noted in the introduction, tricalcium aluminate hexahydrate decomposes under hydrothermal conditions at about $215^{\circ} \mathrm{C}$, yielding calcium hydroxide and a less basic aluminate. The equation may be written

$3\left(3 \mathrm{CaO} \cdot \mathrm{Al}_{2} \mathrm{O}_{3} \cdot 6 \mathrm{H}_{2} \mathrm{O}\right) \rightleftarrows 4 \mathrm{CaO} \cdot 3 \mathrm{Al}_{2} \mathrm{O}_{3} \cdot 3 \mathrm{H}_{2} \mathrm{O}$

$$
+5 \mathrm{Ca}(\mathrm{OH})_{2}+10 \mathrm{H}_{2} \mathrm{O} \text {. }
$$

Data obtained in the present work (experiments 1 and 2 in table 6) indicate that the equilibrium temperature is between $220^{\circ}$ and $226^{\circ} \mathrm{C}$. If a hydrogarnet of composition $3 \mathrm{CaO} \cdot \mathrm{Al}_{2} \mathrm{O}_{3} \cdot m \mathrm{SiO}_{2}$. $(6-2 m) \mathrm{H}_{2} \mathrm{O}$ breaks down in the same manner the silica liberated may be expected to combine with part of the lime.

Table 6 presents data obtained on hydrogarnets and glass compositions covering a wide range of silica content. The hydrogarnets (experiments 3 to 11) were prepared from boiling solutions as described in section 2.3. The silica content indicated was determined by analysis of the product, but it is probable that not all the silica was actually in the hydrogarnet phase, especially in the case of the most highly siliceous preparations (experiments 9 to 11).

All the preparations, with silica ranging up to 2 . moles per mole of $\mathrm{C}_{3} \mathrm{~A}$, when treated hydrothermally at sufficiently high temperatures yielded decomposition products in which $4 \mathrm{CaO} \cdot 3 \mathrm{Al}_{2} \mathrm{O}_{3} \cdot 3 \mathrm{H}_{2} \mathrm{O}$ could be

TABLE 6. Effect of silica on the decomposition temperature of lime-alumina-silica hydrogarnets under hydrothermal conditions

\begin{tabular}{|c|c|c|c|c|c|c|c|}
\hline \multirow{2}{*}{$\begin{array}{l}\text { Exper- } \\
\text { iment }\end{array}$} & \multirow{2}{*}{$\begin{array}{l}\text { Original } \\
\text { material }\end{array}$} & \multirow{2}{*}{$\begin{array}{l}\text { Molar } \\
\text { ratio, } \\
\mathrm{S}: \mathrm{C}_{3} \mathrm{~A}\end{array}$} & \multirow{2}{*}{$\begin{array}{l}\text { Tem- } \\
\text { per- } \\
\text { ature }\end{array}$} & \multirow{2}{*}{$\begin{array}{l}\text { Dura- } \\
\text { tion }\end{array}$} & \multicolumn{3}{|c|}{$\begin{array}{l}\text { Phases present in } \\
\text { product }{ }^{a}\end{array}$} \\
\hline & & & & & $\begin{array}{l}\text { Hydro- } \\
\text { garnet }\end{array}$ & $\mathrm{C}_{4} \mathrm{~A}_{3} \mathrm{H}_{3}$ & $\mathrm{Ca}(\mathrm{OH})_{2}$ \\
\hline & & & ${ }^{\circ} C$ & Days & & & \\
\hline 1. & $\mathrm{C}_{3} \mathrm{AH}_{6 \ldots}$ & 0 & 220 & 7 & + & - & - \\
\hline 2 & do & 0 & 226 & 7 & - & + & + \\
\hline 3 & Hydrogarnet & 0.1 & 231 & 17 & + & - & - \\
\hline 4. & do & 1 & 238 & 7 & + & + & + \\
\hline 5 & _. do ....... & .1 & 261 & $7-$ & - & + & + \\
\hline 6 & _... do . & .3 & 276 & 7 & + & - & - \\
\hline 7 & do . & .3 & 287 & 7 & + & + & + \\
\hline 8 & do & .3 & 307 & 7 & - & + & + \\
\hline 9 & . do . & .6 & 301 & 7 & + & $\frac{1}{-}$ & - \\
\hline 10 & .....do . . & .6 & 313 & 7 & + & + & + \\
\hline 11. & _..._do & .6 & 350 & 7 & - & + & + \\
\hline 12 & Glass & .2 & 210 & 14 & + & 1 & 1 \\
\hline $13 \ldots$ & _. do & 2 & 244 & 7 & + & + & + \\
\hline 14 & _. _ do _. . . . & 4 & 240 & 18 & + & - & - \\
\hline $15 \ldots$ & _.... do ... & .4 & 250 & 14 & + & + & + \\
\hline 16 & $\ldots$..... do . & .4 & 356 & 14 & - & + & + \\
\hline $17 \ldots$ & .... do . . & .5 & 246 & 14 & + & - & - \\
\hline 18 & _. do & .5 & 263 & 14 & + & + & + \\
\hline 19 & _ & .5 & 360 & 7 & - & + & + \\
\hline 20 & _._. do _..... & .7 & 251 & 9 & + & - & - \\
\hline $21 \ldots$ & $\ldots$..... do _. & .7 & 269 & 19 & + & + & + \\
\hline 22 & . & .7 & 372 & 33 & - & + & + \\
\hline $23 \ldots$ & _. _ do . . & 1.2 & 300 & 18 & + & tr. & - \\
\hline $24 \ldots$ & _ & 1. 2 & 371 & 18 & + & + & + \\
\hline 25 & do & 2.0 & 372 & 7 & + & 1 & - \\
\hline $26 \ldots$ & _._._do . . & 2.0 & 400 & 19 & + & + & - \\
\hline
\end{tabular}

${ }^{a}$ +indicates present; -, absent; tr., trace. 


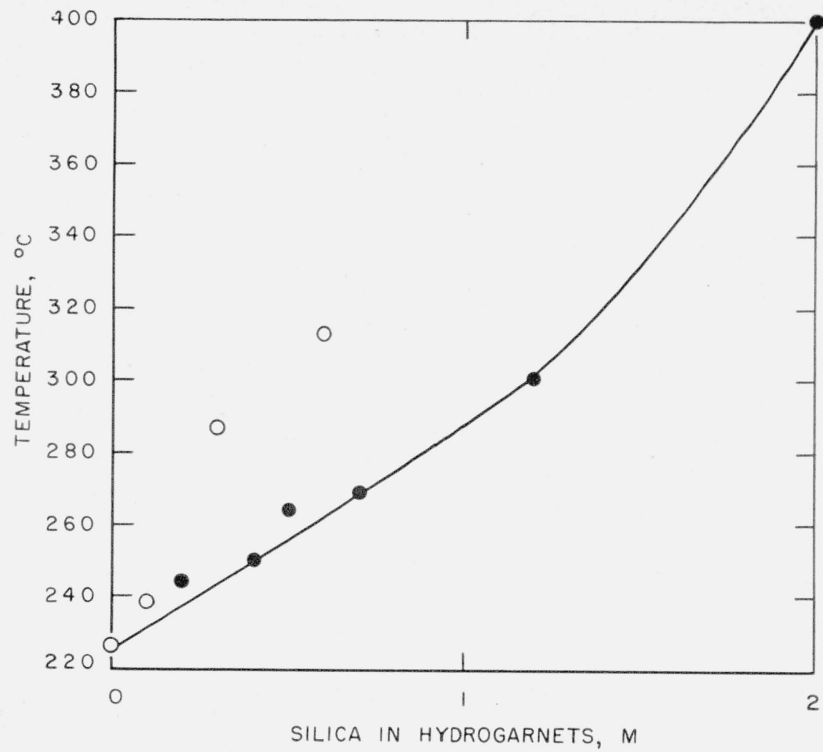

FIGURE 2. Lowest temperature of formation of $4 \mathrm{CaO} \cdot 3 \mathrm{Al}_{2} \mathrm{O}_{3} \cdot 3 \mathrm{H}_{2} \mathrm{O}$ by hydrothermal decomposition of hydrogarnets in the system $\mathrm{CaO}-\mathrm{Al}_{2} \mathrm{O}_{3}-\mathrm{SiO}_{2}-\mathrm{H}_{2} \mathrm{O}$

0 , experiments on hydrogarnets as starting materials; those on glasses.

identified. Calcium hydroxide was also observed except in the most silica-rich preparation, where presumably the lime had all combined with the silica. One or more other phases, usually ill-defined, were also present in the siliceous preparations. These presumably were calcium silicate hydrates, but in most cases they could not be definitely identified.

The minimum temperature of formation of $4 \mathrm{CaO} \cdot 3 \mathrm{Al}_{2} \mathrm{O}_{3} \cdot 3 \mathrm{H}_{2} \mathrm{O}$ is shown as a function of silica content in figure 2. The filled circles, representing data for the glass compositions, fall close to a smooth curve; nevertheless, the diagram should be interpreted with caution, because complete decomposition was not obtained except at considerably higher temperatures. Furthermore, the open circles representing the data for hydrogarnet starting materials are considerably above the curve, whereas under equilibrium conditions they should coincide. As a possible explanation for the discrepancy, it is suggested that the hydrogarnet phase formed from the glass during the warmup period might have been poorer in silica than that formed at the equilibrium. temperature, and therefore subject to decomposition at a lower temperature. If this supposition is correct, the open circles more closely represent the true equilibrium curve.

\subsection{Experiments With Cements}

In view of the possible relation between these reactions and the setting of hydraulic cements, a few tests were made on two cements of domestic manufacture, one aluminous and one portland, to see whether the hydrated aluminate phases could be identified. The anhydrous cement was mixed with water and hydrothermally treated for 1 day.
After treatment at $185^{\circ} \mathrm{C}$ the aluminous cement gave an X-ray pattern in which the lines of a hydrogarnet with unit cell about $12.55 \mathrm{~A}$ could be distinguished. Within the limits of measurement, this could be interpreted as indicating pure tricalcium aluminate hexahydrate or a hydrogarnet containing a very small amount of silica. The other lines of the pattern fit the published patterns of afwillite fairly well, but were too weak for positive identification. A companion sample treated at $250^{\circ} \mathrm{C}$ showed a weaker hydrogarnet pattern plus a number of lines due to $4 \mathrm{CaO} \cdot 3 \mathrm{Al}_{2} \mathrm{O}_{3} \cdot 3 \mathrm{H}_{2} \mathrm{O}$. The latter phase was also observed under the microscope. The $\mathrm{X}$-ray lines attributed tentatively to afwillite remained the same.

It is evident that the hydration of the aluminous cement at $185^{\circ} \mathrm{C}$ produces a hydrogarnet containing little or no silica, despite the presence of sufficient silica in the cement to form a hydrated silicate. It may be noted that similar results were obtained from the mixtures of tricalcium aluminate and tricalcium silicate at comparable temperatures (see, for example, experiments 15 and 21 in table 2 ). The similarity, however, seems to have disappeared at $150^{\circ} \mathrm{C}$.

The sample of portland cement treated hydrothermally at $185^{\circ} \mathrm{C}$ gave a product showing a very weak hydrogarnet pattern with unit cell 12.41 A, indicating the presence of silica in the hydrogarnet phase. Calcium hydroxide was present in larger amount, and the rest of the lines resembled the published patterns for $3 \mathrm{CaO} \cdot \mathrm{SiO}_{2} \cdot 2 \mathrm{H}_{2} \mathrm{O}$. The sample held at $250^{\circ} \mathrm{C}$ gave a similar pattern, with no indication of formation of $4 \mathrm{CaO} \cdot 3 \mathrm{Al}_{2} \mathrm{O}_{3} \cdot 3 \mathrm{H}_{2} \mathrm{O}$. Thus the portland cement differs from the aluminous cement in respect to hydrothermal hydration of its aluminate constituent. It does not necessarily follow that all portland cements would behave in similar manner. The cement used contained 7.1 percent of $\mathrm{Al}_{2} \mathrm{O}_{3}$, which is higher than average. With lower alumina content it might prove impossible to identify any hydrated aluminate by X-ray means.

The results obtained with both cements should be interpreted with caution because of the undetermined effect of the iron, alkalies, and other components present in the cement. Substitution of $\mathrm{Fe}_{2} \mathrm{O}_{3}$ for $\mathrm{Al}_{2} \mathrm{O}_{3}$ would increase the unit cell size [1] and thus might compensate for the effect of higher silica content.

\section{Summary}

Hydrothermal treatment of lime-alumina-silica glasses of the composition of grossularite produced hydrogarnets increasing in silica content with the temperature of formation and approximating the composition of grossularite at $800^{\circ} \mathrm{C}$. The curve was extended at the lower temperature end through the use of glasses poorer in silica.

Mixtures of lime, alumina, and silica as such or in various states of combination, on hydrothermal treatment, usually failed to reach the equilibrium state attained with the glasses. At times as many 
as three distinct hydrogarnet compositions were found to coexist after reaction periods of several days.

The equilibrium temperature for the decomposition of $3 \mathrm{CaO} \cdot \mathrm{Al}_{2} \mathrm{O}_{3} \cdot 6 \mathrm{H}_{2} \mathrm{O}$ under hydrothermal conditions was found to be between 220 and $226^{\circ} \mathrm{C}$, the products being $4 \mathrm{CaO} \cdot 3 \mathrm{Al}_{2} \mathrm{O}_{3} \cdot 3 \mathrm{H}_{2} \mathrm{O}$ and $\mathrm{Ca}(\mathrm{OH})_{2}$. Hydrogarnets containing increasing amounts of silica underwent the same type of decomposition at progressively higher temperatures.

Compounds of the hydrogarnet series were also formed by hydrothermal treatment of aluminous and portland cements. The product of the aluminous cement contained little or no silica, whereas that of the portland cement contained an appreciable amount.

\section{References}

[1] E. P. Flint, H. F. MeMurdie, and L. S. Wells, J. Research NBS 26, 13 (1941) RP135.

[2] E. P. Flint and L. S. Wells, J. Research NBS 27, 171 (1941) RP1411.

[3] H. S. Yoder, Jr., J. Geology 58, 221 (1950)

[4] H. Johnson and T. Thorvaldson, Can. J. Research 21, 236 (1943).

[5] R. B. Peppler and L. S. Wells, J. Research NBS 52, 75 (1954) RP2476.

[6] G. C. Kennedy, Am. J. Sci. 248, 540 (1950).

[7] O. F. Tuttle, Geol. Soc. Am. Bull. 60, 1727 (1949).

[8] L. Heller and H. F. W. Taylor, J. Chem. Soc. 1952, 1018.

[9] R. H. Bogue, Portland Cement Assn. Fellowship Paper No. 69 (Sept. 1954)

[10] H. F. MeMurdie and E. P. Flint, J. Research NBS 31, 225 (1943) RP1560.

[11] R. B. Peppler, J. Research NBS 54, 205 (1955) RP2582,

Washington, March 2, 1956. 